\title{
Indicators of colonization of arbuscular mycorrhizal fungi in "potato" (Solanum tuberosum L.)
}

Indicadores de colonización de hongos micorrícicos arbusculares en "papa" (Solanum tuberosum L.)

\begin{tabular}{l}
\hline Data of the Article \\
\hline National University of San Cristóbal de Huamanga. \\
Biological Sciences Faculty. \\
Independence Portal No.57. \\
Huamanga-Ayacucho. \\
Peru. \\
Tel: (066)312510 - (066)312230. \\
*Contact address: \\
Silvia Méndez-Gálvez \\
National University of San Cristóbal de Huamanga. \\
Biological Sciences Faculty. \\
Independence Portal No.57. \\
Huamanga-Ayacucho. \\
Peru. \\
Tel: (066)312510 - (066)312230. \\
E-mail: silvimega@ @otmail.com \\
silviamendezgalvez@gmail.com \\
\hline
\end{tabular}

\section{J. Selva Andina Biosph.} 2021; 9(1):53-63.

ID of article: 097/JSAB/2020

\section{Record from the article.}

\section{Received September, 2020. \\ Returned december, 2020 \\ Accepted January, 2021.}

Available online, May 2021.

Edited by: Selva Andina Research Society

\section{Palabras clave:}

Hongos micorrícicos arbusculares, Solanum tuberosum

colonización.

\section{, Roberta Esquivel-Quispe ${ }^{(D)}$, Walter Wilfredo Ochoa-Yupanqui}

Arbuscular mycorrhizal fungi (AMF) are soil organisms, they have symbiotic interaction with most plants, they improve the supply of nutrients, growth, and production of host plants, hence their importance as a biofertilizer in agriculture, the objective of this work was to evaluate the effectiveness and infectivity of species of arbuscular mycorrhizal fungi in Solanum tuberosum L. "papa" unique variety. The experiment was carried out under greenhouse conditions, with five treatments: control, Glomus fasciculatum, Entrophospora infrequens, Funneliformis geosporum, Claroideoglomus etunicatum. 75 spores were inoculated per pot (by species and treatment), evaluating the following indicators: length $(\mathrm{cm})$, number of leaves, fresh and dry weight of the aerial part $(\mathrm{g})$, root length $(\mathrm{cm})$, fresh weight, and root dryness (g), number of tubers and stolons, plant vigor, number of spores and percentage of infection, G. fasciculatum, E. infrequens and $F$. geosporum were more effective and $C$. etunicatum, G. fasciculatum and $F$. geosporum showed higher infectivity.

2021. Journal of the Selva Andina Biosphere ${ }^{\circledR}$. Bolivia. All rights reserved.

\section{Resumen}

Los hongos micorrícicos arbusculares (HMA) son organismos del suelo, tienen interacción simbiótica con la mayoría de las plantas, mejoran el suministro de nutrientes, crecimiento y producción de las plantas hospederas, de ahí su importancia como biofertilizante en la agricultura, el objetivo de este trabajo fue evaluar la efectividad e infectividad de especies de hongos micorrícicos arbusculares en Solanum tuberosum L. "papa" variedad única. El experimento se realizó en condiciones de invernadero, con cinco tratamientos: testigo, Glomus fasciculatum, Entrophospora infrequens, Funneliformis geosporum, Claroideoglomus etunicatum. Se inocularon 75 esporas por maceta (por especie y tratamiento), evaluando los siguientes indicadores: longitud $(\mathrm{cm})$, número de hojas, peso fresco y seco de la parte aérea $(\mathrm{g})$, longitud de la raíz $(\mathrm{cm})$, peso fresco y seco de la raíz $(\mathrm{g})$, número de tubérculos y estolones, vigor de la planta, número de esporas y porcentaje de infección, $G$. fasciculatum, E. infrequens y $F$. geosporum tuvieron mayor efectividad y $C$. etunicatum, $G$. fasciculatum y $F$. geosporum mostraron mayor infectividad

2021. Journal of the Selva Andina Biosphere ${ }^{\circledR}$. Bolivia. Todos los derechos reservados 


\section{Introduction}

Soil microorganisms play a role important in the agricultural context, contribute to the functioning of terrestrial ecosystems, through the recovery of degraded soils ${ }^{1}$. The study of arbuscular mycorrhizal fungi (AMF) has taken a lot of importance, to understand the symbiotic relationship that occurs between these fungi and the root system of plants 2 .

AMF are essential constituents of the microbiota natural soil natural ecosystems, probably colonizing more plant tissues than any other type of organisms, play an important role in soil fertility, because these organisms work associated with their roots ${ }^{3.4}$, with a beneficial effect on improving your nutrition, water use, growth, and adaptation to various stressful conditions by biotic as well as abiotic factors ${ }^{5}$.

Colonization by AMF does not cause damage, hyphae develop externally, they branch out distributing on the ground, facilitating its absorption both of nutrients as of wáter ${ }^{6}$.

The effectiveness of a kind of AMF is manifested by its ability to colonize its host, influence positively in its growth, development, the content of nutrients, yield, favoring the multiplication of the propagules of this species in the soil, as a species has a greater magnitude in these three aspects, the greater its effectiveness ${ }^{?}$.

Infectivity refers to the ability of the fungus to penetrate and invade the root intensely and explore the ground, as well as its ability to persist in the productive system ${ }^{8}$. It is influenced by various parameters, such as spore germination, growth of pre-symbiotic mycelia, the formation of appressoria, and intraradical growth ${ }^{2}$. They are currently used in biofertilizers produced from AMF to improve agricultural production, species are especially important native as they present greater possibilities of effectiveness in 54 the field, as they are adapted to conditions of the soil of each region ${ }^{10}$.

Currently, in Ayacucho, there are no investigations performed at the level of effectiveness and infectivity with $\mathrm{AMF}$, for this reason, our objective was: to evaluate the effectiveness and infectivity of these species in "Potato" (Solanum tuberosum L.), inoculating four AMF species: Glomus fasciculatum, Entrophospora infrequens, Funneliformis geosporum, Claroideoglomus etunicatum $\underline{11,12}$.

\section{Materials and methods}

The research was conducted from March to October 2016 in the laboratory and greenhouse of Agro-biology from the Professional School of Agronomy of the University National of San Cristóbal de Huamanga, located between geographic coordinates $13^{\circ} 08^{\prime} 50.92^{\prime \prime}$ south latitude and $74^{\circ} 13$ '09.84", west longitude, at an altitude of 2750 m.s.n.m. with a temperature average maximum of $18{ }^{\circ} \mathrm{C}$, average minimum temperature $10{ }^{\circ} \mathrm{C}, 70-90 \%$ relative humidity, $\mathrm{pH}$ between 6.5-7.5. The soil for the extraction of spores It was from farm fields in the Vinchos district, the extraction, and isolation of spores was carried out according to the Gendermann \& Nicolson $\frac{13}{3}$ and Daniels methodology \& Skipper ${ }^{14}$, also used by other researchers $\frac{15}{}$.

The experimental unit (EU) was made up of a pot with the sterile substrate, host plant, and AMF spores, the extracted substrate was uncultivated soil (virgin soil), collected from non-cultivated areas from the university city of "Pampa del Arco", soil with a sandy clay loam texture (SCL), pH of 7.82 (slightly 
alkaline), the salinity of $0.560 \mathrm{dS} / \mathrm{m}$ (very slightly saline), the percentage of matter organic $1.15 \%$ (low) and a percentage of nitrogen total $0.05 \%$. The soil was sieved and placed in plastic bags in a quantity of $1.5 \mathrm{~kg}$ for its automatic autoclave sterilization for three consecutive days, with a duration of $60 \mathrm{~min}$ at a $100{ }^{\circ} \mathrm{C}$ temperature $(1 \mathrm{~h} / \text { day })^{\frac{16-18}{18}}$. The evaluation of effectiveness and infectivity had a completely randomized experimental design, with four AMF species and the control, with a design conformed for five treatments, four repetitions each, with a total of 20 EU and ordered from as follows: 4 uninoculated pots (control) and 16 pots inoculated with AMF spores, each treatment with a different species. (G. fasciculatum, E. infrequens, F. geosporum, C. etunicatum $)^{9,10}$. The coding used for the treatments was: $T$ (Control), Fg (Funneliformis geosporum), Ce ( $C$. etunicatum), Gf (G. fasciculatum), Ei (E. infrequens). After 110 days, in each EU was evaluated: length of the plant (LP), number of leaves (NL), air fresh weight (AFW), aerial dry weight (ADW) of the plant, root fresh weight (RFW), root dry weight

(RDW), root length (RL). The determination of the number of spores/g of the substrate and the percentage of colonization, calculated with the following formula ${ }^{16}$.

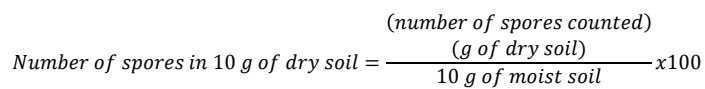

To determine the percentage of colonization, it was used the methodology $\frac{18-20}{}$, and from Giovanetti \& Mosse $^{21}$, was calculated with the following equation: $15,16,20$.

$$
\% \text { total colonization }=\frac{N^{\circ} \text { of colonized segments }}{N^{\circ} \text { of total segments }} \times 100
$$

The data obtained were analyzed with the analysis variance (ANOVA) $)^{16,19}$, using the Infostat at $95 \%$ confidence, as well as the test of comparison of DUNCAN averages at $5 \%$, for determining the effectiveness and infectivity in the different treatments.

\section{Results}

Table 1 Evaluation of the general characteristics of S. tuberosum L. "papa" inoculated with four species of arbuscular mycorrhizal fungi

\begin{tabular}{|c|c|c|c|c|c|c|c|c|c|}
\hline Treatment & PL (cm) & NL & AFW (g) & ADW (g) & RL (cm) & RFW (g) & DRW (g) & WTS & PV \\
\hline $\mathrm{T}$ & 8.25 & 13 & 15.5 & 2.2 & 26 & 5.75 & 3.06 & 0.97 & 2.25 \\
\hline$G f$ & 8.25 & 22.75 & 16.75 & 2.59 & 26.25 & 8.75 & 4.8 & 0.44 & 2.00 \\
\hline$E i$ & 7.25 & 28.75 & 19.5 & 2.86 & 25.75 & 12.75 & 7.43 & 0.65 & 2.25 \\
\hline$F g$ & 6.25 & 16.75 & 21.5 & 2.53 & 17 & 8.75 & 3.08 & 0.17 & 1.50 \\
\hline $\mathrm{Ce}$ & 8.25 & 22 & 17.5 & 2.45 & 20.5 & 11.25 & 4.37 & 1.16 & 2.25 \\
\hline
\end{tabular}

C: Control, Gf: Glomus fasciculatum, Ei: Entrophospora infrequens, Fg: Funneliformis geosporum, Ce: Claroideoglomus etunicatum. PL plant length, NL number of leaves, AFW air fresh weight, ADW aerial dry weight, RL root length, RFW root fresh weight, RDW root dry weigh, WTS weight of tubers and stolons, PV plant vigor.

\section{Discussion}

Mycorrhizal plants need more photosynthates to meet your demand and that of the mycosymbiont in such a way that it allows without affectation stable growth and development of both organisms $\underline{22}$. In
Figure 1, it is shown that the treatment inoculated with $E$. infrequens has a higher quantity in $\mathrm{NH}$ compared to the other treatments (table 1 and figure 6), showing its effect positive when obtaining a larger cup diameter and more leaves in mycorrhizal 
plants $^{\underline{23}, 24}$. It also increases the amount of minerals, such as phosphorus in the increase aerial biomass $\frac{25}{}$.

It also increases the amount of minerals, such as phosphorus in the increase of aerial biomass, increasing its root biomass in mycorrhizal plants ${ }^{26}$, also indicate fewer photosynthates to root growth when acquiring nutrients mainly through mycelium extra radical of mycorrhizal fungi arbuscular (AMF) associated with their roots $\underline{27}, 28$.

Figure 1 Effectiveness of four species of mycorrhizal fungi arbuscular on the number of leaves in S. tuberosum L. "potato"

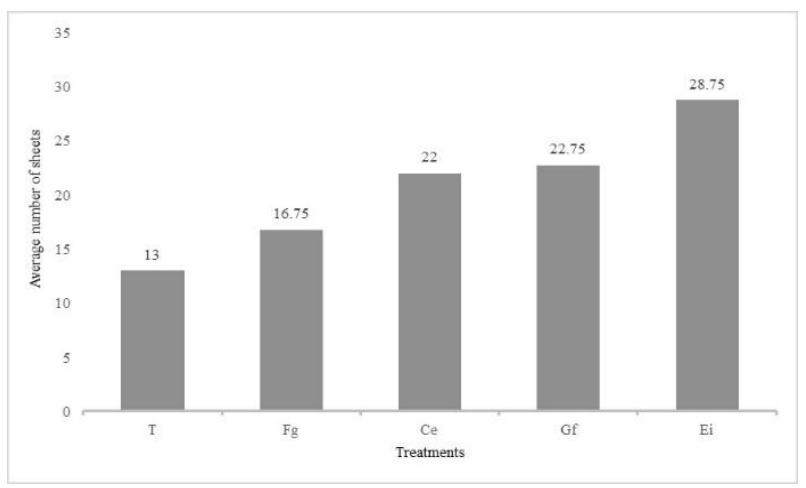

Figure 2 Effectiveness of four species of mycorrhizal fungi arbuscular over aerial fresh weight and aerial dry weight in S. tuberosum L. "potato"

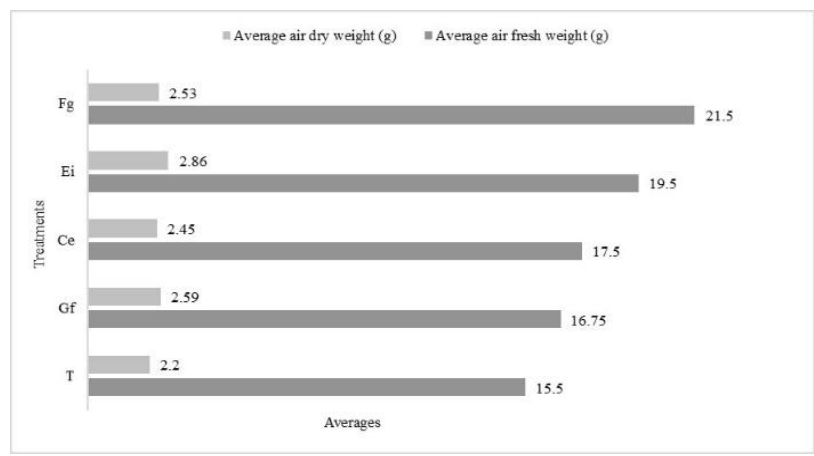

Regarding the effectiveness, on the AFW and ADW, in figure 2 it is observed that the treatment inoculated with $F$. geosporum, is greater. AFW increased by training of spores, compared to treatment without inoculating, these differences are the result of the greater the mycorrhization in plants, the development is better. Plants experience a considerable increase in their biomass mainly due to the improvement of your mineral nutrition induced by the fungus $\underline{29}$.

Figura 3 Efectividad de cuatro especies de hongos micorrícicos arbusculares sobre el peso fresco de raíz y peso seco de raíz en $S$. tuberosum L. "papa"

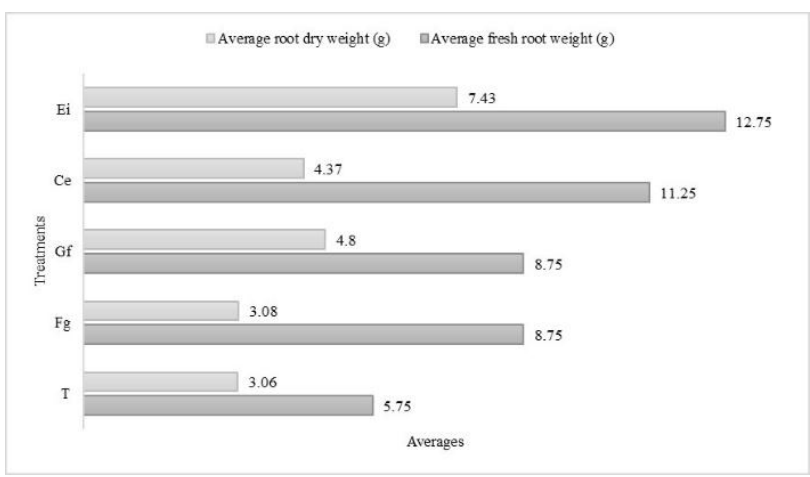

Figura 4 Número de esporas de cuatro especies de hongos micorrícicos arbusculares en $S$. tuberosum $\mathrm{L}$. "papa"

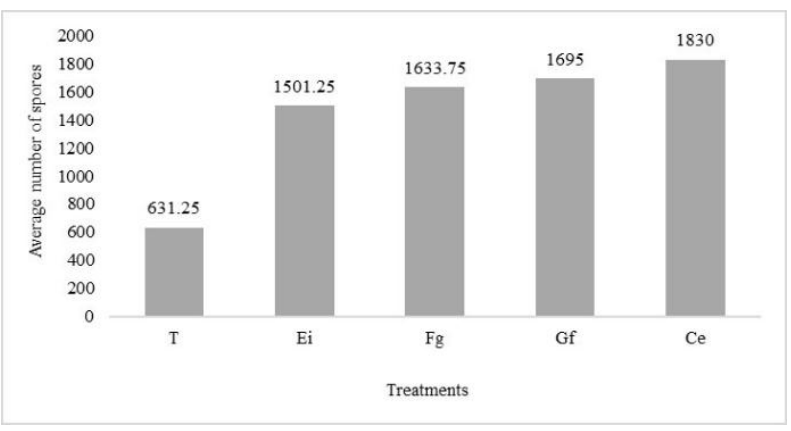

Figure 5 Percentage of infectivity of four species of arbuscular mycorrhizal fungi in S. tuberosum L. "potato"

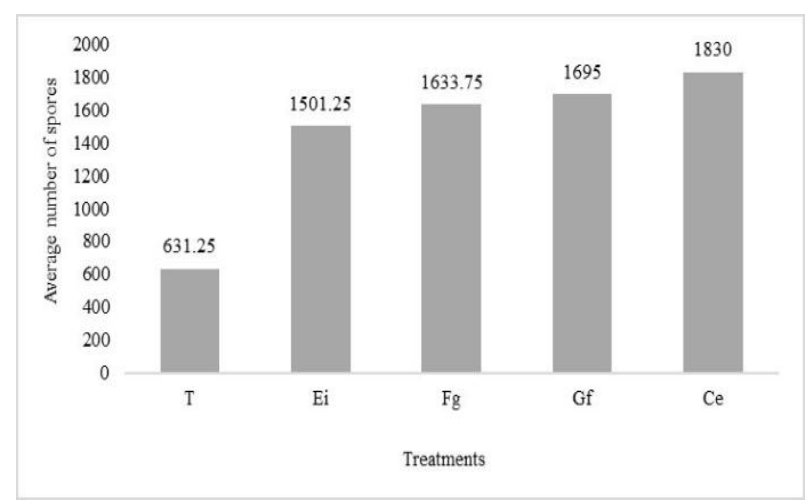


Figure 6 Comparison of the treatments inoculated with different species of AMF versus the control

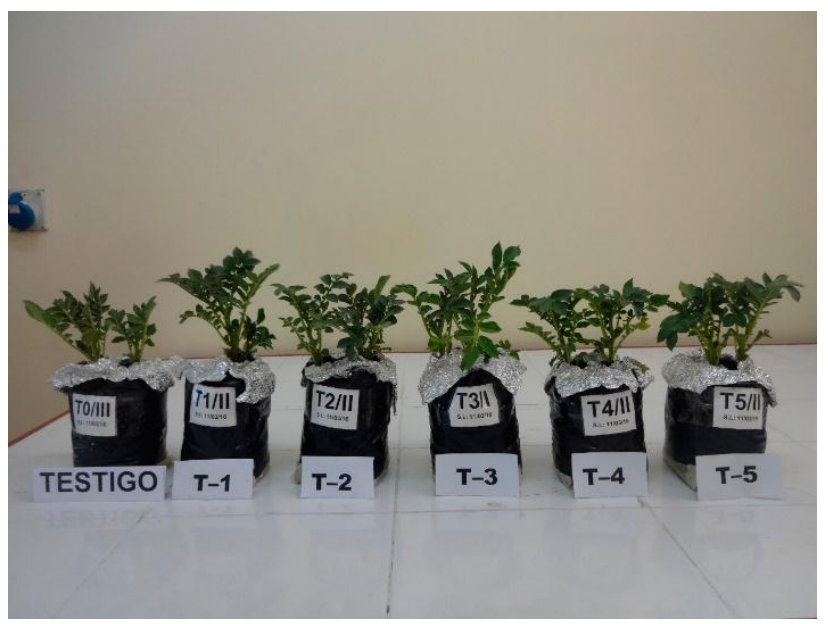

HFMAs increase the survival and biomass production of host plants and improve the absorption of nutrients ${ }^{\frac{28}{4}}$, likewise, they increase the formation of soil microbiota and a rapid re-establishment of the natural biological balance, allowing their greater and rapid growth, to, a rapid generation of a vegetal cover, formation of a greater mass of roots, a better rooting in the substrate, assimilation of nutritive substances that would not otherwise be available to plants ${ }^{29}$.

The ADW is higher with E. infrequens, the ADW ratio of the aerial part is normally higher in plants colonized by mycorrhizae, the response of the plant can vary depending on the degree of dependence between the endophytes and the host plant, as well as the degree of colonization. Likewise, fungal activity represents a cost for the plant, which provides carbonated energy sources for the metabolism of the fungus, hence the generation of a system of mutual benefit ${ }^{-}$. It is important to consider that AMF, are microorganisms that represent up to $50 \%$ of the biomass of soil microorganisms, they form a more relevant symbiosis with more than $90 \%$ 30

The root-mycorrhizal fungus symbiosis stimulates growth in root length density, possibly due to the advantage that mycorrhizal roots possess to explore a greater volume of soil and compensate their nutritional needs, especially capturing those nutrients with little mobility like phosphorus ${ }^{31}$.

In figure 3, the effectiveness of four species is observed of AMF on the RFW and RDW in $S$. tuberosum L. "papa". In which it is observed that the treatments inoculated with $E$. infrequens and $C$. etunicatum have higher RFW (table 1), there seems to be a positive relationship between the presence of $\mathrm{AMF}$ and the increase in the density of your root system. Mycorrhizae increase the formation of soil microflora, rapid restoration of the natural biological balance, allowing greater and faster growth of plants, a rapid generation of a vegetal cover, formation of a greater mass of roots, a better rooting in the substrate, assimilation of nutritive substances that would not otherwise be available ${ }^{29}$.

Table 1 presents the average of the characteristics generals of $S$. tuberosum L. "potato" inoculated with four species of mycorrhizal fungi, results promising in root-fungus symbiosis, due to increased density of the root system, as mycorrhizal roots explore more the soil, received the benefits of the symbiosis of AMF, generally this increase is associated to an increase in the exploration area of the root system, therefore greater availability of nutrients $\frac{32,33}{2}$. AMFs have a very positive effect on biomass production.

The most important effect that mycorrhizae produce on the hosts is an increase in absorption of mineral nutrients from the soil, which results in further growth and development. The main cause of this effect is the expansion of the outer mycelium of the fungus by the rhizospheric soil, which allows the uptake of nutrients beyond the zone of exhaustion that builds up around the roots ${ }^{34}$.

The number of spores has important differences according to where the samples are taken. Various authors have reported variations in the quantification of the number of spores $\frac{33-37}{}$. In figure 4 , it is observed in the treatment inoculated with C. etunicatum (1830 
spores/10 g of soil), statistically similar to the treatments inoculated with $G$. fasciculatum and F. geosporum. Differences in the number of AMF spores in the soil may also be related to different survival strategies of AMF species when living in a given ecosystem, that is, the life cycle of AMF presents a high adaptation to the environment. surrounds, especially during the spore formation stage, in addition, its competitive ability can be affected by various factors 38 depending on the inoculated fungal species. By way of it is generally known that variations in the number of AMF spores may be associated with seasonal patterns of sporulation, which may vary according to the AMF species or the host plant $\frac{39}{\text {. }}$.

The number of AMF spores in the soil not necessarily is reflected in the colonization capacity of these fungi $i^{32,38}$, therefore it is important to make observations in annual periods since the association mycorrhizal can vary through time and space. Figure 5 shows the infectivity percentage of four AMF species in S. tuberosum L. "papa". under greenhouse conditions. G. fasciculatum presents a higher percentage of infection or colonization, being considered more efficient $\underline{22}$, its high infectivity occurs in an early stage and is extensively distributed within the root producing dense infection per entry point $\frac{36}{}$.

The degree of mycorrhizal colonization may depend on various factors such as humidity, temperature, soil $\mathrm{pH}$, luminosity, the oxygen level in the rhizosphere ${ }^{39}$, AMF species and the host plant, together with the AMF biological cycles are synchronized with the phenological cycles and characteristics particular to the plant species to which it is associates increasing the diversity of interactions HMA-plant ${ }^{40}$.

It should be noted that the mycorrhizal treatments were statistically similar to each other and superior to the non-mycorrhized ${ }^{28}$, and in the case of growth parameters the response was different in each species evaluated $^{4,41}$, the HMA consortia state their effectiveness according to their origin.
Several authors affirm that it is necessary to evaluate the effect of some strains and isolated native consortia in these production areas, due to their capacity adaptation and efficiency of these, in addition to reducing economic dependence on commercial biofertilizers $\underline{15}, \underline{42}$.

We conclude that the most effective species were Glomus fasciculatum, Entrophospora infrequens and Funneliformis geosporum, the most infective Claroideoglomus etunicatum, Glomus fasciculatum and Funneliformis geosporum. In this sense, it would be convenient to use G. fasciculatum, E. infrequens, $F$. geosporum and $C$. etunicatum as biofertilizers, carrying out inoculations to improve soil quality, plant productivity, and nutrient absorption.

\section{Funding Source}

The research was developed with self-financing.

\section{Conflicts of interest}

The research corresponds to a degree thesis carried out at the National University of San Cristóbal de Huamanga, for which the authors express the nonexistence of conflicts of interest.

\section{Acknowledgments}

To the FOCAM Project "Recovery, conservation and application of mycorrhizal fungi and native entomopathogens in Vinchos and Chiara. Ayacucho-2012", for the facilities in the materials and equipment.

To Dr. Laura Hernández Cuevas, from the Molecular Biology Laboratory of the Genetics and Environment Research Center of the Autonomous University of Tlaxcala. Mexico. For his valuable contribution in the identification of AMF strains. 
To the National University of San Cristóbal de Huamanga, Faculty of Agrarian Sciences for providing its facilities and equipment.

\section{Ethical considerations}

All procedural and experimental aspects were approved by the evaluation commission of the Faculty of Biological Sciences of the National University of San Cristóbal de Huamanga.

\section{Authors' contribution}

Silvia Méndez Gálvez, conceptualization, idea, investigation and conduct of the investigation, writing of the manuscript. Roberta Esquivel Quispe, development of the research methodology, review, statistical analysis. Walter Wilfredo Ochoa Yupanqui, preparation of tables, writing and final revision of the manuscript.

\section{Cited Literature}

1. Aguilar-Ulloa W, Arce-Acuña P, Galiano-Murillo F, Torres Cruz TJ. Aislamiento de esporas y evaluación de métodos de inoculación en la producción de micorrizas en cultivos trampa. Tecnología en Marcha 2016;24(4):5-14. DOI: https://doi.org/ $\underline{10.18845 / \mathrm{tm} . v 29 \mathrm{i} 7.2700}$

2. Tejena Vergara JP. Diversidad de hongos micorrízicos arbusculares en la Finca Agrofuturo de la Comuna Zapotal, Cantón Santa Elena [tesis licenciatura]. [Guayaquil]: Universidad de Guayaquil; 2012 [citado 20 de mayo de 2019]. Recuperado a partir de: http://repositorio.ug.edu.ec/handle/re$\underline{\mathrm{dug} / 819}$
3. Barrera Berdugo SE. El uso de hongos micorrízicos arbusculares como una alternativa para la agricultura. Rev Bio Agro 2009;7(1):123-32.

4. Acosta Peñaloza D. Aplicación de hongos micorrízicos arbusculares en la producción de plantas de selva baja caducifolia con fines de reforestación [tesis de maestría]. [Cuernavaca]: Universidad Autónoma del Estado de Morelos; 2019. citado 26 de octubre de 2019]. Recuperado a partir de: http://riaa.uaem.mx/xmlui/handle/20.500.12055/7 $\underline{13}$

5. López-Gómez BF, Alarcón A, Quintero-Lizaola R, Lara-Herrera A. Selección de cepas de hongos micorrízicos arbusculares en dos sistemas de producción de Chile. Rev Mex Cienc Agríc 2015; 6(6):1203-14. DOI: https://doi.org/10.29312/remexca.v6i6.567

6. Saboya Pisco A. Evaluación del efecto bioprotector de hongos micorrízicos arbusculares nativos sobre roya (Hemileia vastatrix) en café (Coffea arabica) variedad caturra bajo condiciones de vivero en la Región San Martín [tesis licenciatura]. [Tarapoto]: Universidad Nacional de San Martín; 2018. Recuperado a partir de: http://repositorio.unsm.edu.pe/ handle/11458/3272

7. Martín GM, Arias L, Rivera R. Selección de las cepas de hongos micorrízicos arbusculares (HMA) más efectivas para la Canavalia ensiformis cultivada en suelo Ferralítico Rojo. CulTrop 2010;31(1):27-31.

8. Tapia-Goné JJ, Ferrera-Cerrato R, Varela-Fregoso L, Rodríguez-Ortiz JC, Soria-Colunga JC, Tiscareño-Iracheta $M$, et al. Infectividad y efectividad de hongos micorrízicos arbusculares nativos de suelos salinos en el cultivo de lechuga (Lactuca sativa). Rev Mex Mic. 2010;31:69-74. 
9. Bonilla-Loor MJ, Solórzano Zambrano LJ. Evaluación de la infectividad de comunidades de hongos micorrízicos arbusculares. Pro Sciences 2019;3(21):1-5. DOI: https://doi.org/10.29018/ issn.2588-1000vol3iss21.2019pp1-5

10.Armenta-Bojórquez AD, García-Gutiérrez C, Camacho-Báez JR, Apodaca-Sánchez MÁ, GerardoMontoya L, Nava-Pérez E. Biofertilizantes en el desarrollo agrícola de México. Ra Ximhai 2010;6(1):51-6. DOI: https://doi.org/10.35197/rx. 06.01.2010.07.aa

11.Arbuscular mycorrhizal fungi [Internet]. International culture collection of (vesicular) arbuscular mycorrhizal fungi. 2017 [citado 5 de marzo de 2019]. Recuperado a partir de: http://fungi.invam.wvu.edu/

12.Błaszkowski J. Fungal taxa described [Internet]. Department of Plant Pathology of the Agricultural University of Szczecin, Poland. 2018. [citado 3 de octubre de 2019]. Recuperado a partir de: http://www.zor.zut.edu.pl/Glomeromycota/Blaszkowski\%20Janusz.html

13.Gerdemann JW, Nicolson TH. Spores of mycorrhizal endogone species extracted from soil by wet sieving and decanting. Trans Br Mycol Soc 1963; 46(2):235-44. DOI: https://doi.org/10.1016/S0007 -1536(63)80079-0

14.Daniels BA, Skipper HA. Methods for the recovery and quantitative estimation of propagules from soil. In: Schenck NC, editor. Methods \& Principles of Mycorrhizal Research. American Phytopathological Society: St. Paul; 1982. p. 2935.

15.Martínez Rosales CR. Respuesta del chile ancho (Capsicum annuum L. var. Abedul) a la inoculación con hongos micorrízicos arbusculares [tesis maestría]. [Soledad de Graciano Sánchez]: Universidad Autónoma de San Luis de Potosí; 2016. [citado 16 de septiembre de 2019]. Recuperado a partir de: http://ninive.uaslp.mx/xmlui/handle/i/ $\underline{5857}$

16.Gómez Oré LC. Efecto de concentraciones de esporas de Glomus sp. en Zea mays "maíz"; en condiciones de invernadero [tesis licenciatura]. [Ayacucho]: Universidad Nacional de San Cristóbal de Huamanga; 2015. [citado 6 de octubre de 2019]. Recuperado a partir de: http://repositorio.unsch. edu.pe/handle/UNSCH/ 2254

17.Reyes Tena A, Quiñones Aguilar EE, Rincón Enríquez G, López Pérez L. Micorrización en Capsicum annuum L. para promoción de crecimiento y bioprotección contra Phytophthora capsici L. Rev Mex Cienc Agríc 2016;7(4):857-70. DOI: https:// doi.org/10.29312/remexca.v7i4.260

18.Phillips JM, Hayman DS. Improved procedures for clearing roots and staining parasitic and vesicular-arbuscular mycorrhizal fungi for rapid assessment of infection. Trans $\mathrm{Br}$ Mycol Soc 1970;55(1):158-61. DOI: https://doi.org/10.1016/ $\underline{\text { S0007-1536(70)80110-3 }}$

19.Sagadin MB, Monteoliva MI, Luna CM, Cabello MN. Diversidad e infectividad de hongos micorrícicos arbusculares nativos provenientes de algarrobales del Parque Chaqueño argentino con características edafoclimáticas contrastantes. AgriScientia 2018;35(2):19-33. DOI: https://doi.org/10. 31047/1668.298x.v35.n2.21001

20.Medina Repoma VE. Biogeografía de hongos micorrízicos arbusculares (HMA) en el cultivo de café (Coffea arabica L.) en la región San Martín, Perú [tesis licenciatura]. [Tarapoto]: Universidad 
Nacional de San Martín; 2017 [citado 20 de octubre de 2019]. Recuperado a partir de: http://repositorio.unsm.edu.pe/handle/11458/855

21.Giovanetti M, Mosse B. An evaluation of techniques for measuring vesicular arbuscular mycorrhizal infection in roots. New Phytol 1980;84(3):489-

500. DOI: https://doi.org/10.1111/j.1469-8137. 1980.tb04556.x

22.Ley-Rivas JF, Sánchez JA, Ricardo NE, Collazo E. Efecto de cuatro especies de hongos micorrizógenos arbusculares en la producción de frutos de tomate. Agron Costarricense 2015;39(1):47-59. DOI: https://doi.org/10.15517/rac.v39i1.19544

23.Rodríguez-Gonzales B. Respuesta del tomate (Solanum lycopersicum L.) a la aplicación combinada de hongos micorrízicos arbusculares, un estimulador del crecimiento y fertilizantes minerales [tesis maestría]. [San José de las Lajas]: Instituto Nacional de Ciencias Agrícolas; 2009. [citado 20 de octubre de 2019]. Recuperado a partir de: http://repositorio.geotech.cu/jspui/bitstream/1234/2841/ 1/Respuesta\%20del\%20tomate\%20a\%20la\% 20aplicaci\%C3\%B3n\%20combinada\%20de\%20 hongos\%20micorr\%C3\%ADzicos\%20arbusculares.pdf

24.Lagos Molina SM. Evaluación de cuatro cepas de micorriza arbuscular en plantas de tomate en vivero, Zamorano, Honduras [tesis licenciatura]. [Zamorano]: Escuela Agrícola Panamericana; 2010. citado 26 de octubre de 2019]. Recuperado a partir de: https://bdigital.zamorano.edu/handle/ $\underline{11036 / 605}$

25.Mrabet SE, Lahcen O, Abdelhamid EM, Msanda F, Abbas Y. The effectiveness of arbuscular mycorrhizal inoculation and bio-compost addition for enhancing reforestation with Argania spinosa in
Morocco. Open J For 2014;4(1):14-23. DOI: https://doi.org/10.4236/ojf.2014.41003

26. Soteras F, Renison D, Becerra AG. Growth response, phosphorus content and root colonization of Polylepis australis Bitt. seedlings inoculated with different soil types. New Forests 2013; 44:577-89. DOI: https://doi.org/10.1007/s11056013-9364-X

27.Johnson NC. Resource stoichiometry elucidates the structure and function of arbuscular mycorrhizas across scales. New Phytol 2010;185(3):63147. DOI: https://doi.org/10.1111/j.1469-8137.20 09.03110.x

28. Navarro Ramos SE, Renison D, Becerra AG. La inoculación con hongos micorrícico arbusculares promueve el crecimiento de plantines de Kageneckia lanceolata (Rosaceae). Bol Soc Argent Bot 2018;53(2):161-7. DOI: https://doi.org/10.31055/ 1851.2372.v53.n2.20537

29.Estremayordo Lam RG. Efecto de la aplicación de micorrizas combinadas con abonos orgánicos en la producción de tuberculillos de papa (Solanum tuberosum L.) var. unica, bajo condiciones de invernadero [tesis licenciatura]. [Arequipa]: Universidad Católica de Santa María; 2016. [citado 12 de octubre de 2011]. Recuperado a partir de: http://tesis. ucsm.edu.pe/repositorio/handle/UCSM/5163

30.Pérez Mondaca UA. Evaluación de un sistema para la micorrización in vitro en plantas de mora de castilla (Rubus glaucus) [tesis licenciatura]. [Bogotá]: Pontificia Universidad Javeriana; 2011. [citado 26 de octubre de 2019]. Recuperado a partir de: https://repository.javeriana.edu.co/handle/ $\underline{10554 / 1530}$ 
31.Cabrera Del Águila FT. Efecto Antagónico entre hongos micorrízicos arbusculares (HMA) y nemátodos de nudos (Meloidogyne spp.) en plántulas de sacha inchi (Plukenetia volubilis L.), en la región de San Martín [tesis licenciatura]. [Tarapoto]: Universidad Nacional de San Martín; 2017. [citado 16 de octubre de 2019]. Recuperado a partir de: http://repositorio.unsm.edu.pe/handle/11458/ $\underline{2776}$

32. Ortas I, Sari N, Akpinar Ç, Yetisir H. Screening mycorrhiza species for plant growth, $\mathrm{P}$ and $\mathrm{Zn}$ uptake in pepper seedling grown under greenhouse conditions. Sci Hort 2011;128(2):92-

8. DOI: https://doi.org/10.1016/j.scienta.2010.12. $\underline{014}$

33. Romero Cachique G. Efecto de especies de hongos micorrízicos arbusculares en plántulas de $\mathrm{Co}$ ffea arabica L., variedad caturra en condiciones de vivero en la región San Martín [tesis licenciatura]. [Tarapoto]: Universidad Nacional de San Martín; 2018. [citado 26 de octubre de 2019]. Recuperado a partir de: http://repositorio.unsm.edu.pe/handle/ $11458 / 3279$

34.Paillacho Cedeño FI. Evaluación de la efectividad de las micorrizas arbusculares nativas sobre el desarrollo y estado nutritivo del palmito (Bactris gasipaes HBK) en etapa de vivero, en Santo Domingo de los Tsáchilas [tesis licenciatura]. [Santo Domingo de los Tsáchilas]: Escuela Politécnica del Ejército; 2010. [citado 11 de octubre de 2019]. Recuperado a partir de: http://repositorio.espe. edu.ec/ xmlui/handle/21000/2892

35. Viera W, Campaña D, Lastra A, Vásquez W, Viteri P, Sotomayor A. Micorrizas nativas y su efecto en dos portainjertos de tomate de árbol (Solanum betaceum Cav.). Bioagro 2017;29(2):10514.

36. Salgado García S, Castelán Estrada M, Jiménez Jerónimo R, Gómez Leyva JF, Osorio Miranda M. Diversidad de hongos micorrícicos arbusculares en suelos cultivados con caña de azúcar en la región de la Chontalpa, Tabasco. Rev Mex Mic 2014; 40:7-16.

37.Carballar-Hernández S, Hernández-Cuevas LV, Montaño NM, Larsen J, Ferrera-Cerrato R, Taboada Gaytán OR, et al. Native communities of arbuscular mycorrhizal fungi associated with Capsicum annuиm L. respond to soil properties and agronomic management under field conditions. Agric Ecosyst Environ 2017;245:43-51. DOI: https://doi.org/10.1016/j. agee.2017.05.004

38.Camargo-Ricalde S, Esperón-Rodríguez $\mathrm{M}$. Efecto de la heterogeneidad espacial y estacional del suelo sobre la abundancia de esporas de hongos micorrizógenos arbusculares en el valle semiárido de Tehuacán-Cuicatlán, México. Rev Biol Trop 2005;53(3-4):339-52. DOI: https://doi.org/ 10.15517/rbt.v53i3-4.14594

39.Del Águila Parillo KM. Efecto de la inoculación de hongos micorrízicos arbusculares a plantones de café (Coffea arabica), variedad caturra a nivel de vivero en la región San Martín [tesis licenciatura]. [Tarapoto]: Universidad Nacional de San Martín; 2016. [citado 12 de octubre de 2019]. Recuperado a partir de: http://repositorio.unsm.edu. pe/handle/11458/826

40.Muñoz Cervantes AA, García Sánchez R (dir). Consorcios de hongos micorrizógenos arbusculares asociados a seis especies vegetales provenien- 
tes de matorral xerófilo [tesis licenciatura]. [México]: Universidad Nacional Autónoma de México; 2013. [citado 26 de septiembre de 2019]. Recuperado a partir de: https://www.zaragoza.unam. mx/wp-content/Portal2015/Licenciaturas/biologia/tesis/tesis_munoz_cervantes.pdf

41.Sánchez Santillán T. Efecto de inóculos de hongos micorrízicos arbusculares en plantas clonales de café (Coffea arabica L.) variedad caturra en condiciones de invernadero, Rodríguez de Mendoza, Región Amazonas [tesis licenciatura]. [Chachapoyas]: Universidad Nacional Toribio Rodríguez de Mendoza de Amazonas; 2017. [citado 11 de septiembre de 2019]. Recuperado a partir de: http://repositorio.untrm.edu.pe/handle/UNTRM/
42.Pilco Pomagualli MF, Cabezas Gonzales E (dir). Estudio de las micorrizas asociadas a Miconia bracteolata Bonpl. en el bosque de ceja andina sector Guangra, parroquia Achupallas, cantón Alausí, provincia de Chimborazo [tesis licenciatura]. [Riobamba]: Escuela Superior Politécnica de Chimborazo; 2015. [citado 6 de octubre de 2019]. Recuperado a partir de: http://dspace.espoch.edu.ec/handle/123456789/3885

\section{Editor's Note:}

Journal of the Selva Andina Biophere (JSAB) remains neutral with respect to jurisdictional claims published on maps and institutional affiliations. 